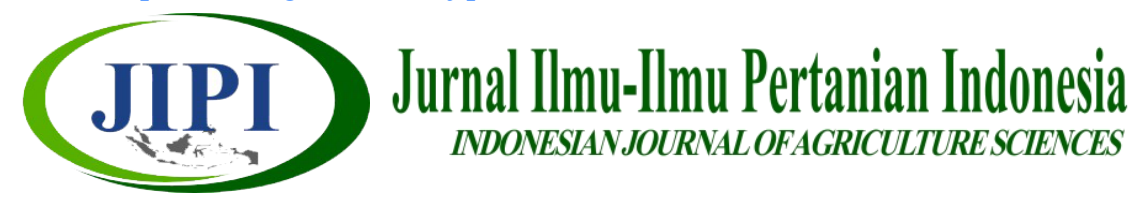

\title{
PENGARUH KOMBINASI DOSIS KOMPOS GULMA DAN PUPUK SINTETIK TERHADAP PERTUMBUHAN DAN HASIL TANAMAN TOMAT (Lycopersicum esculentum Mill.)
}

\author{
Suri Dwijaniati Kurnia ${ }^{1}$, Nanik Setyowati ${ }^{*}$, Alnopri ${ }^{1}$ \\ ${ }^{1}$ Program Studi Agroekoteknologi, Fakultas Pertanian Universitas Bengkulu \\ * Corresponding Author : nsetyowati@unib.ac.id
}

\begin{abstract}
[EFFECT OF WEED COMPOST AND SYNTHETIC FERTILIZER DOSAGE ON TOMATO GROWTH AND YIELD (Lycopersicum esculentum Mill.)]. The growth and yield of tomato plants are influenced by fertilizer and nutrient content in the soil. This study aims to investigate the effect of a combination of synthetic fertilizer and weed compost on the growth and yield of tomato plants. The study was conducted in November 2016 through June 2017 in Agronomy, Faculty of Agriculture, University of Bengkulu, at an altitude of $\pm 10 \mathrm{~m}$ above sea level using a Completely Randomized Design (CRD). The treatments consisted of synthetic fertilizer at a rate of $180 \mathrm{~kg} / \mathrm{ha} \mathrm{N}, 150$ $\mathrm{kg} / \mathrm{ha} \mathrm{P}_{2} \mathrm{O}_{5}$ and $100 \mathrm{~kg} / \mathrm{ha} \mathrm{K} \mathrm{K}_{2} \mathrm{O}$ (control), grass compost 30 , 40 and 50 tons/ha, $50 \%$ control + grass compost 15 tons/ ha, $50 \%$ control +20 tons/ha grass compost and $50 \%$ control +25 tons/ha grass compost. The results revealed that the vegetative growth of tomato plants fertilized with grass compost 30 tons/ha and a combination of grass compost + $50 \%$ control did not differ from control treatment. Tomato yield fertilized with grass compost 30 tons/ha and a combination of $50 \%$ control +15 tons/ha grass compost was higher than the control treatment. Therefore, 15 tons/ha of grass compost can reduce the dose of synthetic fertilizer by $50 \%$.
\end{abstract}

Keyword: compost, weed, tomato, Lycopersicum esculentum

\begin{abstract}
ABSTRAK
Pertumbuhan dan hasil tanaman tomat sangat dipengaruhi oleh pupuk serta kandungan hara dalam tanah. Penelitian ini bertujuan untuk menjelaskan pengaruh kombinasi dosis pupuk sintetik dan kompos gulma terhadap pertumbuhan dan hasil tanaman tomat. Penelitiandilaksanakanpada bulan November 2016 sampai Juni 2017 di rumah kaca Lab. Agronomi, Fakultas Pertanian, Universitas Bengkulu, pada ketinggian tempat $\pm 10 \mathrm{~m}$ dpl menggunakan Rancangan Acak Lengkap (RAL) dengan perlakuan terdiri dari pupuk sintetik dosis rekomendasi $180 \mathrm{~kg} / \mathrm{ha} \mathrm{N}, 150 \mathrm{~kg} / \mathrm{ha} \mathrm{P}_{2} \mathrm{O}_{5}$ dan $100 \mathrm{~kg} / \mathrm{ha} \mathrm{K}_{2} \mathrm{O}$ (kontrol), kompos rumput 30, 40 dan 50 ton/ha, 50\% kontrol + kompos rumput 15 ton/ha, 50\% kontrol+ 20 ton/ha kompos rumput dan 50\% kontrol +25 ton/ha kompos rumput. Tanaman tomat yang dipupuk dengan kompos rumput 30 ton/ha maupun kombinasi kompos rumput $+50 \%$ kontrol pertumbuhannya sama dengan tanaman kontrol. Hasil tanaman tomat yang dipupuk dengan kompos rumput 30 ton/ ha dan kombinasi 50\% kontrol + 15 ton/ha kompos rumput hasilnya lebih tinggi dibandingkan pupuk sintetik dosis rekomendasi. Dengan demikian, pemberian kompos rumput sebanyak 15 ton/ha mampu mengurangi dosis pupuk sintetik sebanyak $50 \%$.
\end{abstract}

Kata kunci: kompos, gulma, tomat, Lycopersicum esculentum 


\section{PENDAHULUAN}

Kondisi media tanam memiliki peran penting dalam menentukan produktivitas tomat. Media tanam yang kandungan unsur haranya rendah dapat mempengaruhi pertumbuhan dan perkembangan tanaman yang pada akhirnya menurunkan hasil. Aplikasi pupuk dalam hal ini dapat memperbaiki kesuburan tanah, karena pupuk mengandung unsur hara yang diperlukan tanaman untuk pertumbuhan serta mempertahankan pertumbuhannya (Sudarmoto, 1997). Pupuk mengandung unsur hara yang dibutuhkan tanaman (Pranata, 2004) dan sedikitnya terdapat 14 unsur hara esensial yang terdiri dari unsur hara makro dan mikro yang diperlukan oleh tanaman untuk pertumbuhan dan perkembangannya (Soepardi, 1983).

Pemberian pupuk diharapkan dapat meningkatkan kesuburan tanah, paling tidak mempertahankannya. Berdasarkan sumber bahannya, pupuk dapat dikelompokkan menjadi dua, yaitu pupuk organik dan pupuk sintetik. Pupuk organik adalah pupuk yang berasal dari makhluk hidup seperti kotoran ternak, sampah organik, kompos maupun limbah tanaman. Sedangkan pupuk sintetik merupakan pupuk buatan yang mengandung unsur kimia (Samekto, 2008).

Pupuk sintetik dapat dikelompokkan menjadi dua yaitu pupuk majemuk dan pupuk tunggal (Sutedjo, 2008). Pupuk tunggal hanya mengandung satu jenis unsur hara seperti urea hanya mengandung unsur $\mathrm{N}$. Tanaman tomat membutuhkan unsur hara dengan dosis yang cukup tinggi, yaitu $180 \mathrm{~kg} / \mathrm{ha} \mathrm{N}, 150 \mathrm{~kg} / \mathrm{ha}$ $\mathrm{P}_{2} \mathrm{O}_{5}$ dan $100 \mathrm{~kg} / \mathrm{ha} \mathrm{K}_{2} \mathrm{O}$ (Balitsa, 1997). Kegiatan budidaya tomat organik tidak menggunakan pupuk sintetik, namun yang digunakan adalah pupuk organik sebagai pupuk dasar yang dosisnya lebih tinggi antara 30-40 ton/ha (Alam Tani, 2016).

Pemberian bahan organik dilakukan untuk meningkatkan dan mempertahankan kesuburan tanah secara berkelanjutan. Penambahan bahan organik membantu dalam memperbaiki tanah yang miskin unsur hara melalui kontribusinya dalam menyediakan unsur hara maupun memperbaiki sifat kimia, fisik maupun biologi tanah. Penambahan bahan organik dapat dilakukan dengan pemberian sisa atau limbah tanaman dan kotoran hewan ke dalam tanah (Hairiah et al. 2000).

Kompos merupakan jenis pupuk organik yang dapat dimanfaatkan untuk memperbaiki sifat-sifat kimia, fisika dan biologi tanah yang pada akhirnya dapat meningkatkan hasil tanaman. Proses dekomposisi pupuk organik yang berlangsung lambat menjadikan unsur hara yang dilepaskan dapat tersedia bagi tanaman untuk jangka waktu cukup lama dan dapat meningkatkan hasil tanaman hingga dua musim tanam. Hasil penelitian Amanullah et al. (2008) menunjukkan, pupuk organik dapatmeningkatkan hasil tanaman hingga dua musim tanam. Pemberian kompos pada berbagai dosis memberikan respon yang berbeda baik terhadap pertumbuhan maupun hasil tanaman. Pemberian kompos sampah kota sampai dosis 30 ton/ha berpengaruh positif terhadap pertumbuhan dan hasil tanaman (Neliyati, 2005).

Kandungan unsur hara yang cukup tinggi dan lengkap menjadikan pupuk organik dapat dimanfaatkan sebagai sumber unsur hara untuk tanaman (Yuniarti et al., 2011; Marliah, 2012; Muktamar et al., 2016 ${ }^{\mathrm{a}}$ ). Beberapa jenis gulma juga dapat dimanfaatkan sebagai sumber pupuk organik (Hartatik, 2007, Setyowati et al.. 2008, Setyowati et al., 2014, Fahrurrozi et al., 2018). Hasil penelitian Muktamar et al. (2017) juga menunjukkan bahwa pupuk organik cair (POC) yang bahan dasamya gulma paitan memiliki efek komplementer terhadap pupuk organik padat (POP) dalam penyediaan hara bagi tanaman. Baik POP maupun POC dapat memperbaiki kualitas tanah dan dapat menyediakan nutrisi tanah. Hasil penelitian Simatupang et al. (2002) menunjukkan, pemberian kompos gulma meningkatkan hasil sejalan dengan meningkatnya dosis kompos gulma yang diberikan. Di samping itu, penggunaan pupuk organik juga dapat memperbaiki kualitas tanah (Muktamar et al., 2016 ${ }^{\mathrm{b}}$ ) serta dapat mengurangi penggunaan pupuk sintetik (Setyowati et al., 2015; Simarmata et al., 2016). Penelitian ini bertujuan untuk menjelaskan pengaruh pupuk sintetik, kompos rumput maupun kombinasi keduanya terhadap pertumbuhan dan hasil tanaman tomat.

\section{METODE PENELITIAN}

Penelitian dilaksanakan pada tahun 2016-2017 di Rumah Kasa Fakultas Pertanian, Universitas Bengkulu, pada ketinggian tempat $\pm 10 \mathrm{~m}$ di atas permukaan laut. Penelitian menggunakan Rancangan Acak Lengkap (RAL) satu faktor yang terdiri atas tujuh taraf perlakuan dan 3 ulangan. Perlakuan yang dimaksud adalah $\mathrm{K}_{1}=$ pupuk sintetik dosis rekomendasi $180 \mathrm{~kg} / \mathrm{ha} \mathrm{N}$ $+150 \mathrm{~kg} / \mathrm{ha} \mathrm{P}_{2} \mathrm{O}_{5}+100 \mathrm{~kg} / \mathrm{ha} \mathrm{K}_{2} \mathrm{O}$ (kontrol); $\mathrm{K}_{2}=$ kompos 30 ton/ha ; $\mathrm{K}_{3}=$ kompos 40 ton/ha; $\mathrm{K}_{4}$ $=$ kompos 50 ton $/ \mathrm{ha} ; \mathrm{K}_{5}=50 \% \mathrm{~K}_{1}+$ kompos 15 ton $/$ ha $; \mathrm{K}_{6}=50 \% \mathrm{~K}_{1}+$ kompos 20 ton $/ \mathrm{ha} ; \mathrm{K}_{7}=50 \%$ $\mathrm{K}_{1}+$ kompos 25 ton/ha. 


\section{Pembuatan kompos}

Penelitian diawali dengan pembuatan kompos rumput. Rumput sebagai bahan baku kompos didapatkan dari lahan bera atau sepanjang jalan di Kota Bengkulu. Seratus kg gulma tersebut dicacah dengan ukuran 3-5 cm, kemudian ditempatkan dalam wadah pengompos dan ditambah $25 \mathrm{~kg}$ pupuk kandang. Campuran tersebut diaduk secara merata serta ditambah air sampai kondisinya lembab. Selanjutnya membuat larutan dengan komposisi 500 g gula pasir, $50 \mathrm{~mL}$ EM-4 dan air lalu didiamkan satu malam. Setelah itu, larutan tersebut disiramkan ke dalam campuran rumput dan pupuk kandang secara merata. Bahan tersebut kemudian ditumpuk dalam ruangan pengomposan dan dilakukan pembalikan seminggu sekali selama dua bulan. Kompos yang matang dicirikan dengan warnanya yang coklat kehitaman, tidak mengeluarkan aroma yang menyengat, tetapi mengeluarkan aroma seperti bau tanah serta apabila dikepal, kompos akan mengumpal. Apabila ditekan, gumpalan akan hancur dan remah. Kompos matang yang sudah dingin selanjutnya siap untuk digunakan.

\section{Penanaman, pemeliharaan dan panen}

Jenis tanah yang digunakan adalah ultisol. Tanah yang diambil kemudian dikeringanginkan selama 3 hari. Setelah 3 hari dilakukan pengayakan meggunakan ayakan yang berdiameter $2 \mathrm{~mm}$. Setelah itu tanah dimasukkan ke dalam polibag yang berukuran 40 $\mathrm{cm}$ x $50 \mathrm{~cm}$ sebanyak $10 \mathrm{~kg} /$ polibag. Penyemaian benih dilakukan dalam kotak persemaian (plastic tray) dengan media campuran tanah dan pupuk kandang kambing dengan perbandingan 1:1 (v:v). Benih dipindahkan ke polibag setelah berumur 14 hari, telah memiliki tinggi sekitar $8-10 \mathrm{~cm}$ dan jumlah daun 4-5 helai serta sehat atau tidak terserang hama dan penyakit. Pemupukan dilakukan satu minggu sebelum pindah tanam dengan dosis sesuai perlakuan. Pupuk diaplikasikan dengan cara mencampurkan tanah dengan pupuk secara merata. Setiap polibag yang telah diberi pupuk tersebut ditanami 1 bibit tomat.

Pemeliharaan yang dilakukan meliputi penyiraman, penyulaman, penyiangan, pengajiran, dan pengendalian hama dan penyakit. Penyulaman dilakukan 1 minggu setelah tanam pada tanaman yang layu, terserang hama dan penyakit atau mati. Penyiangan dilakukan secara manual dengan mencabut gulma yang tumbuh di sekitar tanaman. Pengajiran dilakukan saat tanaman berumur 3-4 minggu. Pengendalian penyakit dilakukan secara manual dengan cara membuang buah yang terserang penyakit busuk buah. Panen dilakukan pada buah yang telah memenuhi kriteria warna buahnya mulai menguning atau jingga. Panen dilakukan 8 kali dengan interval waktu 3-4 hari.

\section{Pengumpulan dan analisis data}

Variabel yang diamati meliputi tinggi tanaman, umur muncul bunga pertama, diameter batang, jumlah cabang, umur panen, jumlah buah/tanaman, diameter buah, bobot buah/buah, bobot buah/tanaman, bobot segar atas, bobot segar akar, bobot kering atas dan bobot kering akar.

Data dianalisis secara statistik dengan Analisis Varians (ANAVA) atau uji F pada taraf 5\%. Variabel yang berbeda nyata diuji lanjut dengan Duncan's Multiple Range Test (DMRT) pada taraf 5\% (Freund \& Wilson, 2003).

\section{HASIL DAN PEMBAHASAN}

Hasil analisis data menunjukkan bahwa terdapat perbedaan yang tidak nyata $(\mathrm{P}>0,05)$ pertumbuhan vegetatif tanaman yang disebabkan oleh perlakuan yang diberikan kecuali diameter batang. Namun terdapat perbedaan yang nyata $(\mathrm{P} \leq 0,05)$ terhadap jumlah buah maupun bobot buah/tanaman. Variabel pertumbuhan lainnya seperti umur berbunga, umur panen, diameter buah maupun bobot tiap buah tidak dipengaruhi oleh perlakuan.

Terdapat perbedaan yang tidak nyata pertumbuhan tanaman tomat, baik yang dipupuk dengan pupuk sintetik $\left(\mathrm{K}_{1}\right)$, pupuk kompos pada kisaran dosis 30 - 50 ton/ha $\left(\mathrm{K}_{2}, \mathrm{~K}_{3}, \mathrm{~K}_{4}\right)$, maupun kombinasi pupuk sintetik pada dosis $50 \%$ dari dosis kontrol dengan kompos $\left(\mathrm{K}_{5}, \mathrm{~K}_{6}, \mathrm{~K}_{7}\right)$ (Tabel 1). Dengan demikian kompos pada dosis 30 ton/ha telah dapat menggantikan peran pupuk sintetik. Hal yang sama didapatkan pada perlakuan pengurangan dosis pupuk sintetik hingga $50 \%$ yang ditambah dengan kompos pada dosis 15 ton/ha. Meski demikian perlakuan yang diberikan berpengaruh terhadap diamater batang. Tanaman tomat yang dipupuk dengan kompos pada dosis 40 ton/ha diameter batangnya lebih besar $(9,45 \mathrm{~cm})$ dibandingkan yang hanya dipupuk dengan pupuk sintetik pada dosis rekomendasi $(6,14 \mathrm{~cm})$.

Perlakuan yang diuji berpengaruh tidak nyata $(\mathrm{P}>0,05)$ terhadap umur berbunga, umur panen, dan diameter buah namun berpengaruh nyata $(\mathrm{P} \leq 0,05)$ terhadap jumlah buah dan bobot buah/tanaman (Tabel 2). Secara umum, tanaman yang hanya dipupuk dengan pupuk sintetik $\left(\mathrm{K}_{1}\right)$ jumlah buah maupun bobot buahnya lebih kecil dibandingkan tanaman yang dipupuk dengan kompos maupun kombinasi kompos + pupuk sintetik (Tabel 2). Tanaman yang dipupuk kompos 30 ton/ha $\left(\mathrm{K}_{2}\right)$ hasilnya lebih tinggi dibandingkan dengan yang hanya dipupuk sintetik $\left(K_{1}\right)$. Kenaikan dosis dari 30 ton/ha ke 40 ton/ha $\left(\mathrm{K}_{3}\right)$ dapat meningkatkan hasil secara signifikan. 
KURNIA et al.

Tabel 1. Pengaruh dosis pupuk sintetik, kompos rumput dan kombinasi keduanya terhadap pertumbuhan vegetatif tanaman tomat

\begin{tabular}{|c|c|c|c|c|c|c|c|}
\hline Perlakuan & $\begin{array}{l}\mathrm{TT} \\
(\mathrm{cm})\end{array}$ & $\begin{array}{c}\mathrm{DB} \\
(\mathrm{mm})\end{array}$ & $\mathrm{JC}$ & $\begin{array}{c}\text { BSA } \\
(\mathrm{g})\end{array}$ & $\begin{array}{l}\text { BSK } \\
(\mathrm{g})\end{array}$ & $\begin{array}{l}\mathrm{BKA} \\
(\mathrm{g})\end{array}$ & $\begin{array}{c}\mathrm{BKK} \\
(\mathrm{g})\end{array}$ \\
\hline $\mathrm{K}_{1}=$ pupuk sintetik dosis $180 \mathrm{~kg} \mathrm{~N}+$ & & & & & & & \\
\hline $\begin{array}{l}150 \mathrm{~kg} / \mathrm{ha}_{2} \mathrm{O}_{5}+100 \mathrm{~kg} / \mathrm{ha} \mathrm{K}_{2} \mathrm{O} \\
\text { (kontrol) }\end{array}$ & 62,18 & $6,14 \mathrm{c}$ & 1 & 25,08 & 4,72 & 6,77 & 1,51 \\
\hline $\mathrm{K}_{2}=$ kompos 30 ton $/ \mathrm{ha}$ & 81,49 & $7,39 \mathrm{bc}$ & 1 & 42,03 & 3,88 & 10,76 & 1,51 \\
\hline $\mathrm{K}_{3}=\mathrm{kompos} 40$ ton $/ \mathrm{ha}$ & 86,65 & $9,45 \mathrm{a}$ & 2 & 93,67 & 5,99 & 22,12 & 1,78 \\
\hline $\mathrm{K}_{4}=\mathrm{kompos} 50$ ton $/ \mathrm{ha}$ & 75,22 & $7,73 \mathrm{bc}$ & 1 & 46,69 & 4,04 & 12,08 & 1,43 \\
\hline $\mathrm{K}_{5}=50 \% \mathrm{~K}_{1}+$ kompos 15 ton $/ \mathrm{ha}$ & 88,83 & $7,99 \mathrm{ab}$ & 2 & 96,59 & 6,19 & 23,45 & 2,09 \\
\hline $\mathrm{K}_{6}=50 \% \mathrm{~K}_{1}+$ kompos 20 ton $/ \mathrm{ha}$ & 76,09 & $7,56 \mathrm{bc}$ & 2 & 38,33 & 4,94 & 10,66 & 1,54 \\
\hline $\mathrm{K}_{7}=50 \% \mathrm{~K}_{1}+$ kompos 25 ton $/ \mathrm{ha}$ & 74,33 & $6,94 \mathrm{bc}$ & 2 & 47,40 & 5,29 & 11,71 & 1,73 \\
\hline
\end{tabular}

Keterangan : angka-angka yang diikuti oleh huruf yang sama pada kolom yang sama berbeda tidak nyata pada taraf $5 \%$, TT (tinggi tanaman), DB (diameter batang), JC (jumlah cabang), BSA (bobot segar atas), BSK (bobot segar akar), BKA (bobot kering atas), BKK (bobot kering akar)

Tabel 2. Pengaruh dosis pupuk sintetik, kompos rumput dan kombinasi keduanya terhadap pertumbuhan generatif tanaman tomat

\begin{tabular}{|c|c|c|c|c|c|c|}
\hline Perlakuan & $\begin{array}{l}\text { UB } \\
\text { (hst) }\end{array}$ & $\begin{array}{l}\mathrm{UP} \\
\text { (hst) }\end{array}$ & JB & $\begin{array}{c}\mathrm{DB} \\
(\mathrm{mm})\end{array}$ & $\begin{array}{c}\text { BTB } \\
\text { (g/buah) }\end{array}$ & $\begin{array}{c}\mathrm{BB} \\
(\mathrm{g} / \tan )\end{array}$ \\
\hline $\begin{array}{l}\mathrm{K}_{1}=\text { pupuk sintetik dosis } 180 \mathrm{~kg} \mathrm{~N}+ \\
150 \mathrm{~kg} / \mathrm{ha}_{2} \mathrm{O}_{5}+100 \mathrm{~kg} / \mathrm{ha} \mathrm{K}_{2} \mathrm{O} \\
\text { (kontrol) }\end{array}$ & 35 & 68 & $5 \mathrm{c}$ & 13,11 & 25,15 & $115,85 \mathrm{c}$ \\
\hline $\mathrm{K}_{2}=\mathrm{kompos} 30$ ton $/ \mathrm{ha}$ & 31 & 66 & $6 \mathrm{c}$ & 17,75 & 34,74 & $211,82 \mathrm{~b}$ \\
\hline $\mathrm{K}_{3}=\mathrm{kompos} 40$ ton $/ \mathrm{ha}$ & 28 & 59 & $17 \mathrm{a}$ & 27,52 & 23,29 & 402,39 a \\
\hline $\mathrm{K}_{4}=\mathrm{kompos} 50$ ton $/ \mathrm{ha}$ & 29 & 66 & $13 \mathrm{ab}$ & 19,93 & 20,59 & $249,73 \mathrm{~b}$ \\
\hline $\mathrm{K}_{5}=50 \% \mathrm{~K}_{1}+$ kompos 15 ton $/ \mathrm{ha}$ & 30 & 64 & $15 \mathrm{a}$ & 23,69 & 28,32 & 392,77 a \\
\hline $\mathrm{K}_{6}=50 \% \mathrm{~K}_{1}+$ kompos 20 ton $/ \mathrm{ha}$ & 30 & 63 & $9 \mathrm{bc}$ & 23,23 & 25,80 & $232,05 \mathrm{~b}$ \\
\hline $\mathrm{K}_{7}=50 \% \mathrm{~K}_{1}+$ kompos 25 ton $/ \mathrm{ha}$ & 33 & 64 & $6 \mathrm{c}$ & 17,78 & 30,39 & $171,77 \mathrm{bc}$ \\
\hline
\end{tabular}

Keterangan : angka-angkayang diikuti oleh huruf yang sama pada kolom yang sama berbeda tidak nyata pada taraf $5 \%$; UB (umur berbunga), UP (umur panen), JB (jumlah buah), DB (diameter buah), BTB (bobot tiap buah), BB (bobot buah/tanaman)

Pengurangan $50 \%$ dosis pupuk sintetik yang dikombinasikan dengan kompos 15 ton/ha hasil tomatnya lebih tinggi dibandingkan tanaman kontrol $\left(\mathrm{K}_{1}\right)$. Hasil penelitian menunjukkan, tanaman tomat yang dipupuk dengan pupuk sintetik (kontrol) maupun yang dipupuk dengan kompos maupun kombinasi keduanya menghasilkan pertumbuhan vegetatif tanaman tomat yang berbeda tidak nyata, kecuali terhadap diameter batang (Tabel 1). Tinggi tanaman berkisar antara 62 $\mathrm{cm}-88 \mathrm{~cm}$ dengan jumlah cabang antara 1- 2. Dengan demikian, selama periode vegetatif tanaman mendapatkan unsur hara dalam jumlah yang memadai dari masingmasing perlakuan bagi pertumbuhan tanaman.

Memasuki periode generatif, terjadi perubahan respon tanaman terhadap perlakuan yang diberikan. Tanaman kontrol menghasilkan buah yang lebih sedikit dengan ukuran buah yang lebih kecil dibandingkan perlakuan lainnya. Hasil tertinggi dihasilkan dari tanaman yang dipupuk dengan kompos 40 ton/ha dan kombinasi perlakuan 50\% kontrol + kompos 15 ton/ha. Dari kedua perlakuan ini didapatkan buah dengan jumlah yang lebih banyak dengan ukuran yang lebih besar dibandingkan kontrol. Jumlah buah pada tanaman kontrol hanya 5 buah/tanaman dengan diameter 13,11 mm sedangkan pada perlakuan kompos 40 ton/ha sebesar 17 dengan diameter buah 27,52 mm dan kombinasi perlakuan 50\% kontrol + kompos 15 ton/ha jumlah buahnya 15 dengan diamater buahnya 23,69 mm. Di samping itu, perlakuan kompos pada dosis 30 ton/ha hasilnya juga lebih tinggi $(211,82$ $\mathrm{g} / \tan )$ dibandingkan kontrol $(115,85 \mathrm{~g} / \tan )$. Hasil ini menunjukkan adanya peran kompos dalam kontribusinya terhadap penyediaan unsur hara bagi tanaman maupun dalam memperbaiki struktur tanah sehingga akar 
dapat tumbuh dan berkembang dengan baik. Akar yang tumbuh dan berkembang baik akan menghasilkan serapan hara yang lebih efisien.

Peran pupuk sintetik seperti Urea, SP-36,dan $\mathrm{KCl}$ adalah untuk memenuhi kebutuhan hara tanaman. Nitrogen merupakan unsur hara utama bagi pertumbuhan yang diperlukan untuk pembentukan atau pertumbuhan bagian-bagian vegetatif tanaman, seperti daun, batang, dan akar. Jika $\mathrm{N}$ dalam tanah tidak dapat memenuhi kebutuhan unsur hara tanaman, maka perlu tambahan $\mathrm{N}$ dalam tanah yang berasal dari sumber lain. Jika hal tersebut tidak terpenuhi, maka pertumbuhan dan perkembangan tanaman akan terganggu. Fosfor berperan dalam mempercepat pertumbuhan akar, memperkuat pertumbuhan tanaman, mempercepat pembungaan, dan pemasakan biji, sedangkan peranan $\mathrm{K}$ pada tanaman adalah untuk meningkatkan kualitas biji dan buah, meningkatkan retensi tanaman terhadap organisme penggangu tanaman, mengeraskan batang tanaman, dan berperan dalam proses sintesis protein dan karbohidrat (Roesmarkam \& Yuwono, 2002). Dalam penelitian ini, tanaman yang hanya dipupuk dengan pupuk sintetik pertumbuhan vegetatifnya tidak berbeda dengan tanaman yang dipupuk dengan kompos saja maupun kombinasi keduanya. Dengan demikian kompos yang diberikan berperan dalam pertumbuhan dan hasil tanaman.

Pupuk organik memiliki peran yang besar dalam menyediakan unsur hara bagi tanaman maupun perbaikan sifat fisik tanah. Hal tersebut menjadikan tanaman yang dipupuk dengan kompos pertumbuhannya sebagus tanaman yang dipupuk dengan pupuk sintetik (Tabel 1). Pupuk organik berasal dari berbagai bahan organik yang merupakan hasil dari sisa pelapukan mahluk hidup seperti tanaman dan hewan yang terdapat di dalam tanah yang terus menerus mengalami proses dekomposisi oleh jasad renik. Bahan organik tanah memiliki peran penting dalam kemampuan tanah untuk mendukung produktivitas tanaman. Di samping itu, bahan organik tanah dapat menyediakan nutrisi untuk aktivitas mikroba yang juga dapat meningkatkan dekomposisi bahan organik, meningkatkan stabilitas agregat tanah, dan meningkatkan daya serap air (Sutanto, 2002).

Bahan organik tanah menjadi salah satu indikator kesehatan tanah karena memiliki beberapa peranan didalam tanah. Fungsi bahan organik tanah meliputi fungsi biologi dapat menyediakan makanan dan tempat hidup (habitat) bagi organisme tanah, menyediakan energi untuk proses biologi tanah, dan memberikan kontribusi pada daya serap air (resistensi) tanah; fungsi kimia merupakan ukuran kapasitas retensi hara tanah, memberikan kontribusi pada daya serap air (resistensi) tanah, dan menyimpan cadangan unsur hara penting seperti N, P, dan K; dan fungsi fisika dapat mengikat partikel-partikel tanah menjadi lebih remah untuk meningkatkan stabilitas struktur tanah, meningkatkan kemampuan tanah dalam menyimpan air, dan menjaga suhu tanah.
Hasil penelitian menunjukkan, tanaman yang dipupuk dengan kompos pada dosis 30 ton/ ha atau lebih hasilnya lebih tinggi dibandingkan yang hanya dipupuk dengan pupuk sintetik saja maupun kombinasi kompos + pupuk anorganik (Tabel 2). Hasil ini menunjukkan kontribusi kompos dalam penyediaan unsur hara dan perbaikan media tanam. Media tanam yang mendukung pertumbuhan tanaman akan menjadikan akar efektif dalam penyerapan unsur hara sehingga dapat meningkatkan hasil tanaman. Weil \& Magdoff (2004) menyatakan bahwa fungsi tanah antara lain menyediakan nutrisi tanaman untuk diserap akar, menahan air untuk pertumbuhan tanaman dan sebagai tempat perkembangbiakan mikroorganisme tanah. Hasil penelitian yang dilakukan oleh Sudjatmiko et al. (2018) pada budidaya organik menunjukkan dinamika kandungan kimia tanah seperti C-total, N-total, Ptersedia, $\mathrm{K}-\mathrm{dd}$, Al-dd maupun $\mathrm{pH}$ tanah yang selalu berubah tergantung pada waktu dan jenis tanaman yang ditanam. Pupuk organik yang diaplikasikan dalam bentuk cair juga berpengaruh terhadap sifat kimia tanah yang diindikasikan dengan meningkatnya $\mathrm{pH}$ tanah dan K-dd (Anggita et al., 2018).

Kompos di samping berperan menyediakan unsur hara juga memperbaiki struktur tanah sehingga akar dapat tumbuh lebih leluasa dan tanaman dapat tumbuh lebih baik. Tabel 2 menunjukkan kontribusi kompos dalam pertumbuhan dan hasil tanaman. Hasil penelitian ini sejalan dengan hasil penelitian Lubis (2018) yang menunjukkan, pupuk kandang ayam berpengaruh terhadap pertumbuhan dan hasil tanaman jagung dan tanaman mentimun (Tufalia, 2014). Setyowati et al. (2018) menyatakan bahwa kompos tithonia mengandung $0.85 \% \mathrm{~N}, 0.22 \% \mathrm{P}$ dan $0.63 \% \mathrm{~K}$ yang diaplikasikan pada kol bunga pada dosis 25 ton/ha hasilnya lebih tinggi. Pemberian pupuk organik yang berasal dari tandan kosong kelapa sawit, sludge, vermikompos, kompos jerami serta kompos sampah kota juga dapat meningkatkan bobot kering umbi bawang merah (Anisyah et al., 2014).

Pupuk biourine yang diaplikasikan pada tanaman bayam berpengaruh terhadap total- $\mathrm{N}$ dalam tanah, K-tersedia, dan C-organik serta tinggi tanaman maupun bobot segarnya (Dharmayanti et al., 2013). Hasil penelitian lain juga menunjukkan, pemberian kompos jerami dapat meningkatkan kandungan $\mathrm{N}$-tanah serta meningkatkan tinggi tanaman dan jumlah anakan/ rumpun padi sawah. Kompos jerami padi bersamasama dengan pupuk NPK dapat meningkatkan serapan $\mathrm{N}$ pada padi sawah (Kaya, 2013). Penggabungan antara pupuk anorganik dengan organik menghasilkan panjang tongkol, diameter tongkol maupun bobot pipilan kering jemur yang lebih tinggi dibandingkan aplikasi secara mandiri (Dewanto et al., 2013). Hasil penelitian yang dilakukan menunjukkan, kompos rumput yang dikombinasikan dengan pupuk NPK hasilnya juga lebih tinggi dibandingkan tanpa kompos (tanaman 
kontrol). Diduga, kompos yang diberikan dapat meningkatkan serapan unsur hara oleh tanaman tomat. Dengan demikian pemberian kompos rumput sebesar 15 ton/ha dapat mengurangi dosis pupuk NPK sebanyak $50 \%$ dengan hasil yang lebih tinggi. Hasil serupa dinyatakankan oleh Wicaksono (2018) bahwa pemberian pupuk hijau paitan sebanyak 10 ton/ha mampu mengurangi dosis pupuk NPK sebesar $25 \%$.

\section{KESIMPULAN}

Tanaman tomat yang dipupuk dengan kompos rumput 30 ton/ha maupun kombinasi kompos rumput + $50 \%$ dosis rekomendasi pupuk sintetik pertumbuhannya sama dengan tanaman yang dipupuk dengan pupuk sintetik pada dosis rekomendasi $(180 \mathrm{~kg} \mathrm{~N}, 150 \mathrm{~kg}$ $\mathrm{P}_{2} \mathrm{O}_{5}$ dan $100 \mathrm{~kg} / \mathrm{ha} \mathrm{K}_{2} \mathrm{O}$ ). Hasil tanaman tomat yang dipupuk dengan kompos rumput 30 ton/ha dan kombinasi $50 \%$ kontrol +15 ton/ha kompos rumput hasilnya lebih tinggi dibandingkan pupuk sintetik dosis rekomendasi. Dengan demikian, pemberian kompos rumput sebanyak 15 ton/ha mampu mengurangi dosis pupuk sintetik sebanyak 50\%.

\section{DAFTAR PUSTAKA}

Alam Tani. (2016). Panduan Teknis Budidaya Tomat. http://alamtani.com/budidava-tomat.html. Diakses 25 Oktober 2016.

Amanullah, K.E.Z., Horiuchi, T. \& Matsui, T. (2008). Effects of compost and green manure of pea and their combinations with chicken manure and rapeseed oil residue on soil fertility and nutrient uptake in wheatrice cropping system. African Journal of Agricultural Research, 3(9), 633-639.

Anggita, T., Muktamar, Z. \& Fahrurrozi. (2018). Improvement of selected soil chemical properties and potassium uptake by mung bean after application of liquid organic fertilizer in Ultisol. Terra, 1(1), 1-7.

Anisyah, F., Sipayung, R. \& Hanum, C. (2014). Petumbuhan dan produksi bawang merah dengan pemberian berbagai pupuk organik. Jurnal Online Agroekoteknologi, 2 (2), 482-496.

Balitsa. (1997). Teknologi Produksi Tomat. Balai Penelitian Tanaman Sayuran, Bandung.

Dewanto, F.G., Londok, J.J.M.R., Tuturoong, R.A.V. \& Kaunang, W.B. (2013). Pengaruh pemupukan anorganik dan organik terhadap produksi tanaman jagung sebagai sumber pakan. Jurnal Zootek, 32(5), 1-8.

Dharmayanti, N.S., Supadma, A.A.N. \& Arthagama, I.D.M. (2013). Pengaruh pemberian biourine dan dosis pupuk anorganik $(\mathrm{N}, \mathrm{P}, \mathrm{K})$ terhadap beberapa sifat kimia tanah Pegok dan hasil tanaman bayam (Amaranthus sp.). E-Jurnal Agroekoteknologi Tropika, 2(3), 165-174.
Fahrurrozi, F., Sariasih, Y., Muktamar, Z., Setyowati, N., Chozin, M. \& Sudjatmiko, S. (2018). Identification of nutrient contents in six potential green biomasses for developing liquid organic fertilizer in closed agriculturel production system. International Journal on Advanced Science Engineering Information Technology, 7(2), 559-565.

Freund, R. \& Wilson, W. (2003). Statistical Methods. Academic Press, London.

Hairiah, K., Widianto, H., Utami, S.R., Suprayogo, D., Sunaryo, Sitompul, S.M., Lusiana, B., Mulia, R., Van Noordwijk, M. \& Cadisch, G. (2000). Pengelolaan Tanah Masam Secara Biologi. ICRAF. Bogor.

Hartatik, W. (2007). Tithonia diversifolia sumber pupuk hijau. Warta Penelitian dan Pengembangan Pertanian, 29(5), 3-5.

Kaya. (2013). Pengaruh kompos jerami dan pupuk NPK terhadap N-tersedia tanah, serapan-N, pertumbuhan dan hasil padi sawah (Oryza sativa L.). Agrologia, 2(1), 43-50.

Lubis, B.K., Setyowati, N. \& Hasanudin. (2018). Respon pertumbuhan dan hasil tanaman jagung terhadap berbagai dosis pupuk kandang ayam dan jarak tanam. UNES Journal Agricultural Scienties,2(2), 125-137.

Marliah, A. (2012). Pemanfaatan pupuk organik cair terhadap pertumbuhan dan hasil beberapa varietas tomat (Lycopersicum esculentum L.). Jurnal Agrista, 16(3), 122-128.

Muktamar, Z., Fahrurrozi, F., Dwatmadji, D., Setyowati, N. Sudjatmiko, S. \& Chozin, M. $\left(2016^{\mathrm{a}}\right)$. Selected macronutriens uptake by sweet corn under different rates liquid organic fertilizer in closed agriculture system. International Journal on Advanced Science Engineering Information Technology, 6(2), 258-261.

Muktamar, Z., Justisia, B. \& Setyowati, N. (2016 ${ }^{\mathrm{b}}$. Quality enhancement of humid tropical soils after aplication of water hyacinth (Eichornia crassipes) compost. Journal of Agricultural Technology, 12(7), 1211-1227.

Muktamar, Z., Sudjatmiko, S., Fahrurrozi, F., Setyowati, N. \& Chozin, M. (2017). Soil chemical improvement under aplication of liquid organic fertilizer in closed agriculture system. International Journal of Agricultural Technology, 13(7.2), 1715-1727.

Neliyati. 2005. Pertumbuhan dan hasil tanaman tomat pada beberapa dosis kompos sampah kota.Jurnal Agronomi, 10(2), 93-97.

Pranata, A.S. (2004). Pupuk Organik Cair Aplikasi dan Manfaatnya. Agromedia Pustaka, Jakarta.

Roesmarkam \& Yuwono. (2002). Ilmu Kesuburan Tanah. Kanisius, Yogyakarta.

Samekto, R. (2008). Pemupukan. PT Citra Aji Parama, Yogyakarta. 
Setyowati, N., Nurjanah, U. \& Haryanti, D. (2008). Gulma tusuk konde (Wedelia trilobat) dan krinyu (Chromolaena adorata) sebagai pupuk organik pada Sawi (Brassica chinensis L.). Jurnal Akta Agrosia, 11 (1), 47-56.

Setyowati, N., Muktamar, Z., Oktiasa, S., \& Ganefianti, D.W. (2014). Growth and yield of chili pepper under different time application of wedelia (Wedelia triobata) and Siam weed (Chromolaena odorata) organic fertilizers.International Journal on Advanced Science Engineering Information Technology, 4(6), 13-16.

Setyowati, N., Muktamar, Z. \& Puspitasari, I. (2015). Weed based organic fertilizer to recude aplication of synthetic in Mustard (Brassica sinensis L.). Journal of Agricultural Technology, 11(8), 1677-1683.

Setyowati, N., Sudjatmiko, S., Muktamar, Z., Fahrurrozi, F., Chozin, M. \& Simatupang, P. (2018). Growth and yield responses of cauliflower on tithonia (Tithonia diversifolia) compost under organic farming practices. International Journal of Agricultural Technology, 14(7), 1905-1914.

Simarmata, M., Susanti, L. \& Setyowati, N. (2016). Utilization of manure and green organic compost as alternative fertilizers for cauliflower producion. Journal of Agricultural Technology, 12(2), 311-319.

Simatupang, R. S., Raihan, H.S., Rasmadi, H.M. \& Siagian, T.H. (2002). Pengaruh kompos gulma sebagai sumber hara $\mathrm{N}$ terhadap pertumbuhan dan hasil padi di tanah sulfat masam. Jurnal Ilmiah Agroscientiae, 9(2), 106-117.

Soepardi, G. (1983). Kesuburan dan Pemupukan Tanah Pertanian. Pustaka Buana, Bandung.
Sudarmoto, A. S. (1997). Budidaya Tanaman Jagung. Kanisius,Surabaya.

Sudjatmiko, S., Muktamar, Z., Chozin, M., Setyowati, N. \& Fahrurrozi, F. (2018). Changes in chemical properties of soil in an organic agricultural system. ICOAT 2017. IOP Conf. Series: Earth and Environmental Science, 215(2018) 012016. doi:10.1088/1755-1315/215/1/012016

Sutanto, R. (2002). Penerapan Pertanian Organik: Pemasyarakatan dan Pengembangannya. Kanisius, Yogyakarta.

Sutedjo, M. M. (2008). Pupuk dan Pemupukan. CV. Simplex, Jakarta.

Tufalia, M., Laksana, D.D. \& Alam, A. (2014). Aplikasi kompos kotoran ayam untuk meningkatkan hasil tanaman mentimun (Cucumis sativus L.) di tanah masam. Jurna Agroteknos,4(2),120-127.

Weil, R.R. \& Magdoff, F. 2004. Significance of Soil Organic Matter to Soil Quality and Health. In: Magdoff, E. \& Weil, R. R. (eds). Soil Organic Matter in Sustainable Agriculture. CRC Press, London. pp:1-44.

Wicaksono, A.T. \& Sumarni, T. (2018). Pengaruh pupuk NPK dan pupuk hijau paitan (Tithonia diversifolia) pada pertumbuhan dan hasil jagung (Zea mays L.) var. P-21. Jurnal Produksi Tanaman, 6(8), 1620-1626.

Yuniarti, A., Machfud, Y. \& Mita. (2011). Aplikasi pupuk organik, NPK, dan BPF pada ultisols untuk meningkatkan C-Organik, N-total, serapan N dan hasil jagung manis (Zea mays saccharata Sturt L.). Jurnal Agroekotek, 6(1), 21-30. 